\title{
Molecular detection of Anaplasmataceae agents in Dasyprocta azarae in northeastern Brazil
}

\author{
Detecção molecular de agentes Anaplasmataceae em Dasyprocta azarae no nordeste do Brasil
}

Maria do Socorro Costa de Oliveira Braga ${ }^{1}$; José Gomes Pereira ${ }^{1}$; Simone de Jesus Fernandes ${ }^{2}$;

Ingrid Carolinne Lopes Marques ${ }^{1}$; Renata Passos de Jesus ${ }^{1}$; Gleycianny Santos Ferreira ${ }^{1}$; Daniele Rosa Xavier ${ }^{1}$; Jyan Lucas Benevenute²; Rosangela Zacarias Machado; Marcos Rogério André2*

\author{
${ }^{1}$ Universidade Estadual do Maranhão - UEMA, São Luís, MA, Brasil \\ ${ }^{2}$ Faculdade de Ciências Agrárias e Veterinárias, Universidade Estadual Paulista - UNESP, Jaboticabal, SP, Brasil
}

Received July 6, 2017

Accepted November 13, 2017

\begin{abstract}
Recently, the importance of wild-living rodents for maintenance of pathogens of the family Anaplasmataceae in the environment was investigated. These mammals play a role as reservoirs for these pathogens and act as hosts for the immature stages of tick vectors. The aim of the present study was to investigate the prevalence of Ehrlichia sp. and Anaplasma sp. in 24 specimens of Azara's agouti (Dasyprocta azarae) that had been trapped in the Itapiracó Environmental Reserve, in São Luís, Maranhão, northeastern Brazil, using molecular methods. Four animals (16.7\%) were positive for Ehrlichia spp. in nested PCR assays based on the 16S rRNA gene. In a phylogenetic analysis based on the 16S rRNA gene, using the maximum likelihood method and the GTRGAMMA+I evolutionary model, Ehrlichia sp. genotypes detected in Azara's agoutis were found to be closely related to E. canis and to genotypes relating to E. canis that had previously been detected in free-living animals in Brazil. The present work showed the first molecular detection of Ehrlichia sp. in Azara's agoutis in Brazil.
\end{abstract}

Keywords: Azara’s agouti, Ehrlichia, rodents, molecular characterization.

\section{Resumo}

Recentemente, a importância de roedores selvagens na manutenção de agentes Anaplasmataceae no ambiente tem sido investigada, haja visto o papel que tais mamíferos podem desempenhar como reservatórios para os patógenos e como hospedeiros para estágios imaturos dos carrapatos vetores. O presente estudo objetivou investigar a ocorrência de Ehrlichia sp. e Anaplasma sp. em 24 cotias (Dasyprocta azarae) capturadas na Reserva Ambiental de Itapiracó, em São Luís, Maranhão, nordeste do Brazil, utilizando métodos moleculares. Quatro animais (16,7\%) mostraram-se positivos nos ensaios de nested PCR para Ehrlichia spp. baseados no gene 16S rRNA gene. Na análise filogenética baseda no gene $16 \mathrm{~S}$ rRNA e utilizando o método de Máxima Verossimilhança e modelo evolutivo GTRGAMMA+I, os genótipos de Ehrlichia sp. detectados em cotias mostraram-se filogeneticamente relacionados às sequências de $E$. canis e outros genótipos relacionados a $E$. canis detectados previamente em animais selvagens no Brasil. O presente trabalho mostrou a primeira detecçấo molecular de Ehrlichia sp. em cotias no Brasil.

Palavras-chave: Cotias, Ehrlichia, roedores, caracterização molecular.

The bacteria belonging to the genera Anaplasma and Ehrlichia are obligate intracellular parasites that replicate in intracytoplasmic vacuoles of neutrophils, monocytes, macrophages and erythrocytes (DUMLER et al., 2001), thus forming microcolonies called morulae. These agents are associated with infections in humans and several species of domestic and free-living animals. Most

*Corresponding author: Marcos Rogério André. Laboratório de Imunoparasitologia, Departamento de Patologia Veterinária, Faculdade de Ciências Agrárias e Veterinárias "Júlio de Mesquita Filho" - UNESP, Campus de Jaboticabal, Via de Acesso Prof. Paulo Donato Castellane, s/n, Zona Rural, CEP 14884-900, Jaboticabal, SP, Brasil. e-mail: marcos_andre@fcav.unesp.br cases of ehrlichiosis and anaplasmosis described in humans are tick-borne zoonoses (DOUDIER et al., 2010; ISMAIL et al., 2010; WOLDEHIWET, 2010).

Ixodid ticks are competent vectors for $A$. phagocytophilum in the northern hemisphere (RIZZOLI et al., 2014). In Brazil, $A$. phagocytophilum has been molecularly detected in Rhipicephalus sanguineus sensu lato and Amblyomma sculptum (cited as A. cajennense) in the state of Rio de Janeiro (SANTOS et al., 2013). While Amblyomma americanum is considered to be the main vector for Ehrlichia ewingii and E. chaffeensis in North America (RAR \& GOLOVLJOVA, 2011), Dermacentor variabilis and Ixodes pacificus 
possibly act as vectors in other regions (WALKER et al., 2004). Ehrlichia canis is transmitted by Rhipicephalus sanguineus and Dermacentor variabilis (LITTLE, 2010; RAR \& GOLOVLJOVA, 2011). Few studies in Brazil have investigated the vector competence of ticks in the epidemiological cycles of pathogens of the family Anaplasmataceae. Recently, it was demonstrated that only the tropical lineage of $R$. sanguineus (SANCHES et al., 2016) showed vector competence for transmitting E. canis among dogs in South America (MORAES-FILHO et al., 2015).

Recently, the importance of free-living rodents for maintenance of pathogens of the family Anaplasmataceae in the environment was investigated. These mammals play a role as reservoirs for these pathogens and act as hosts for the immature stages of tick vectors (FOLEY et al., 2002; OBIEGALA et al., 2014; RIZZOLI et al., 2014).

In the United States, certain rodent species like Tamias ochrogenys exhibit demographic characteristics, such as high population density and ability to remain infected for long periods of time, that contribute towards transmission of Anaplasma phagocytophilum, the etiological agent of human granulocytic anaplasmosis (NIETO \& FOLEY, 2009). Moreover, dispersal of this rodent species may facilitate the spread of infected ticks to other vertebrate hosts (NIETO \& FOLEY, 2009). The rodent species Neotoma fuscipes has been shown to be an important source of infection for the DU-1, HZ, MRK and Dog_CA strains of A. phagocytophilum. It acts as a reservoir for this agent and as hosts for the immature stages of ixodid ticks, which have been recognized as vectors for granulocytic agents of anaplasmosis in the northern hemisphere (NIETO et al., 2010; REJMANEK et al., 2012).

On the other hand, in Europe, prevalence of $A$. phagocytophilum $(22.8 \%)$ was reported among rodents belonging to the species Apodemus sylvaticus, Apodemus flavicollis and Myodes glareolus, which were sampled in different regions of France (CHASTAGNER et al., 2016). In Germany, Obiegala et al. (2014) found low prevalence of A. phagocytophilum (1.1\%) among the rodent species A. sylvaticus, Myodes glareolus and A. flavicollis. Similarly, low prevalence of A. phagocytophilum (0.2\%-2.2\%) was also reported among rodents in Slovakia (SVITÁLKOVÁ et al., 2015; BLAŇAROVÁ et al., 2014).

Only a few studies have been conducted in Brazil regarding the prevalence of Anaplasmataceae agents in rodents. For instance, Wolf et al. (2016) detected Anaplasma sp. in a specimen of Hylaeamys megacephalus that had been trapped in the Pantanal of the state of Mato Grosso. More recently, among 458 rodents sampled in different regions of Brazil, Benevenute et al. (2017) reported prevalences of $1.09 \%$ and $1.96 \%$ for Ehrlichia sp. and Anaplasma sp., respectively, using previously described conventional PCR (cPCR) assays based on the 16S rRNA gene. Additionally, prevalences of $0.44 \%$ and $2.40 \%$ for Ehrlichia sp. and Anaplasma sp., respectively, were reported in the same study, using a newly designed multiplex quantitative real-time PCR based on the groEL gene (BENEVENUTE et al., 2017).

Azara's agoutis (Dasyprocta azarae) are rodents of terrestrial habit that are distributed in rainforests (Amazon Forest and Atlantic Forest), semi-deciduous forests, savanna and caatinga, and are usually found close to water courses (BONVICINO et al., 2008). Considering the scarcity of studies relating to detection of pathogens of the family Anaplasmataceae in rodents in Brazil, the aim of the present study was to investigate the prevalence of Ehrlichia sp. and Anaplasma sp. in Azara's agoutis that had been trapped in the Itapiracó Environmental Reserve, in São Luís, Maranhão, northeastern Brazil.

Between January and May 2016, blood samples were collected from 24 Azara's agoutis (16 females and 8 males) that had been trapped in the Itapiracó Environmental Reserve (322 hectares), in the municipality of São Luís, state of Maranhão, northeastern Brazil (Figure 1). The rodents were caught using live traps (Sherman ${ }^{\circledR}$; H. B. Sherman Traps, Tallahassee, FL, USA; and Tomahawk ${ }^{\circledR}$; Tomahawk Live Traps, Tomahawk, WI, USA) baited with a mixture of banana, peanut butter, oats and sardine. The traps were set up on seven consecutive nights along linear transects, placed on the ground at ten-meter intervals. The total capture effort was 50 trap-nights. After blood sampling, the animals were ringed and weighed (mean values of $2.65 \mathrm{~kg}$ and $2.45 \mathrm{~kg}$ for males and females, respectively). All the animal trapping was done in accordance with the licenses obtained from the Brazilian government's Institute for Wildlife and Natural Resource Care (IBAMA) and was endorsed by the Ethics Committee of the State University of Maranhão, São Luis, Maranhão, Brazil), under no. 004/2016.

DNA was extracted from $200 \mu \mathrm{L}$ of whole blood from each sample, using the QIAamp DNA blood mini kit (QIAGEN ${ }^{\circledR}$, Valencia, CA, USA), in accordance with the manufacturer's instructions. DNA concentration and quality were measured using the 260/280 nm absorbance ratio (Nanodrop ${ }^{\circledR}$, Thermo Fisher Scientific, Waltham, MA, USA). In order to verify the presence of amplifiable DNA in the samples, an internal control PCR assay targeting a fragment of mammalian glyceraldehyde-3-phosphate dehydrogenase (GAPDH) (BIRKENHEUER et al., 2003) was performed.

Conventional PCR assays targeting the 16S rRNA gene of Ehrlichia spp. (MURPHY et al., 1998) and Anaplasma spp. (MASSUNG et al., 1998) were performed, following previously described protocols. In order to achieve further molecular characterization, positive samples were subjected to CPCR assays targeting groESL/Ehrlichia and Anaplasma spp. (SUMNER et al., 1997, NICHOLSON et al., 1999, LOTRIC-FURLAN et al., 1998) omp-1/Ehrlichia spp. (INAYOSHI et al., 2004), and dsb/E. canis (DOYLE et al., 2005). Ehrlichia canis (DE SOUSA et al., 2013), Ehrlichia chaffeensis and Anaplasma phagocytophilum DNA (kindly supplied by Prof. John Stephen Dumler, Uniformed Services University of the Health Sciences, Bethesda, MD, USA) were used as positive controls in cPCR assays. The cPCR assays contained 10X PCR buffer (Life Technologies ${ }^{\circledR}$, Carlsbad, CA, USA), $1 \mathrm{mM}$ of $\mathrm{MgCl}_{2}$ (Life Technologies ${ }^{\circledR}$, Carlsbad, CA, USA), $0.2 \mathrm{mM}$ of deoxynucleotide triphosphate (dNTPs) mixture (Life Technologies ${ }^{\circledR}$, Carlsbad, CA, USA), $1.5 \mathrm{U}$ of Taq DNA polymerase (Life Technologies $^{\circledR}$, Carlsbad, CA, USA) and $0.5 \mu \mathrm{M}$ of each primer (Integrated DNA Technologies ${ }^{\circledR}$, Coralville, IA, USA) (Table 1). Ultra-pure water (Promega ${ }^{\circledR}$ ) was used as a negative control in all PCR assays. In order to prevent PCR contamination, the DNA extraction, reaction setup, PCR amplification and electrophoresis were performed in separate rooms. The gels were imaged under ultraviolet light using the Image Lab software version 4.1 (Bio-Rad $\left.{ }^{\circledR}\right)$. The reaction products were purified using the Silica Bead DNA gel extraction kit (Thermo Fisher Scientific ${ }^{\circledR}$, Waltham, MA, USA). 


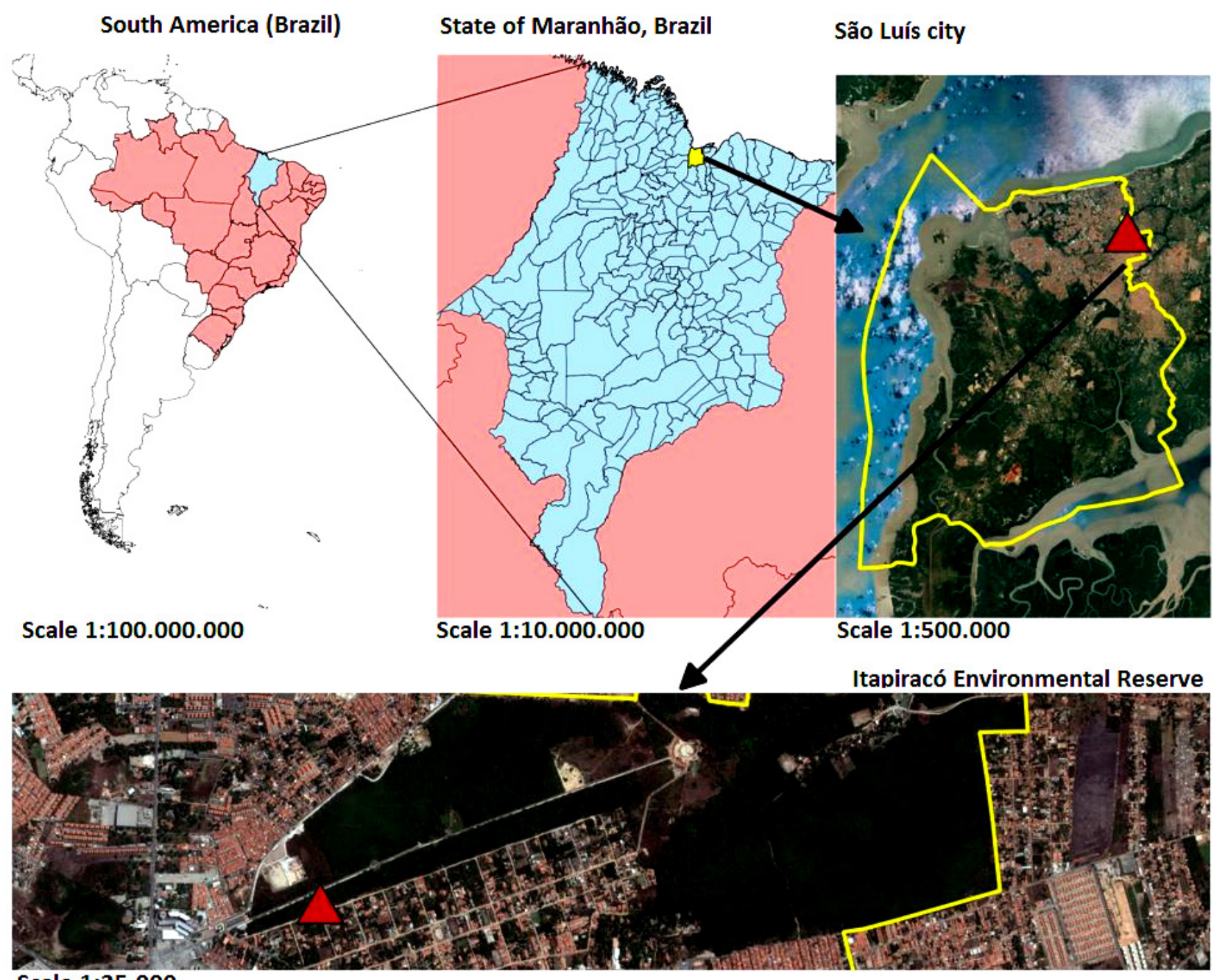

Scale 1:25.000

Figure 1. Map of Reserva Ambiental do Itapiracó, São Luís city, state of Maranhão, northeastern Brazil, where Azara’s agouti blood samples were collected between January and May 2016.

Sanger sequencing was performed using the BigDye ${ }^{\circledR}$ Terminator v3.1 cycle sequencing kit (Thermo Fisher Scientific ${ }^{\circledR}$, Waltham, MA, USA) and the ABI PRISM 310 DNA analyzer (Applied Biosystems $^{\circledR}$, Foster City, CA, USA) (SANGER et al., 1977).

Sequences obtained from positive samples were first subjected to a screening test using the Phred-Phrap software, version 23 (EWING \& GREEN, 1998; EWING et al., 1998), in order to evaluate the electropherogram quality and obtain consensus sequences through alignment of sense and antisense sequences. The BLAST software (ALTSCHUL et al., 1990) was used to analyze the nucleotide sequences (BLASTn), with the aim of browsing through them and comparing them with sequences that had previously been deposited in an international database (GenBank) (BENSON et al., 2017). All sequences that showed appropriate quality standards and similarity with Ehrlichia spp. or Anaplasma spp. were deposited in GenBank. The sequences were aligned with sequences that had previously been published in GenBank, using the MAFFT software, version 7 (KATOH \& STANDLEY, 2013).

Phylogenetic inferences were made based on the maximum likelihood (ML) method. The ML analysis was done using the RAxML-HPC BlackBox software 7.6.3 (STAMATAKIS et al., 2008) (which includes estimation of bootstrap node support), using 1000 bootstrapping replicates. The best evolutionary model (GTRGAMMA+I) was selected through the jModelTest2 software (version 2.1.6) on XSEDE (DARRIBA et al., 2012), under the Akaike Information Criterion (AIC) (POSADA et al., 2004). All phylogenetic analyses were performed using the CIPRES Science Gateway (MILLER et al., 2010). The trees were examined using Treegraph 2.0.56-381 beta (STOVER \& MULLER, 2010).

The samples from all 24 Azara's agoutis amplified a GAPDH gene fragment. Four animals (16.7\%) were positive for Ehrlichia spp. 
Table 1. Description of oligonucleotides, PCR product size and references used in CPCR assays for Ehrlichia spp. and Anaplasma spp.

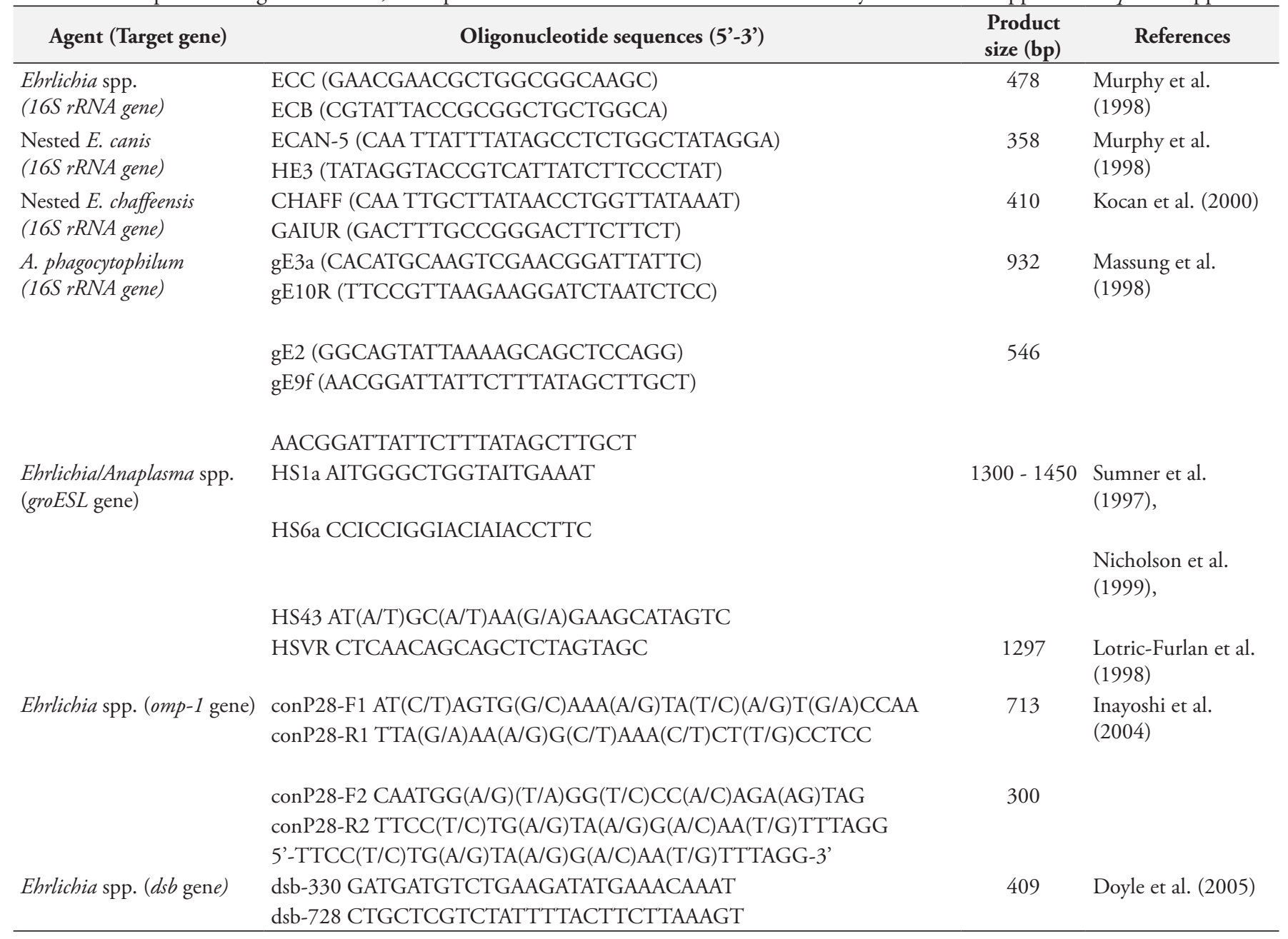

in nested PCR assays based on the 16S rRNA gene. Three out of four positive amplicons were subjected to sequencing based on a high-intensity band that was observed on agarose gel. The sequences obtained (MF435278 - Dasyprocta \#1; MF435279 - Dasyprocta \#3; and MF435280 - Dasyprocta \#18) showed 98-99\% similarity to E. canis (GenBank access numbers KX766395.1, KJ995838.1 and KC109445.1). All the samples were negative for Anaplasma spp. in cPCR assays based on the $16 \mathrm{~S}$ rRNA. Samples that were positive for Ehrlichia spp. based on the 16S rRNA gene were negative in cPCR assays based on groESL, $d s b$ and $o m p-1$ genes, thus precluding further molecular characterization. In the phylogenetic analysis based on the 16S rRNA gene using the maximum likelihood method and GTRGAMMA+I evolutionary model, the Ehrlichia sp. genotypes detected in Azara's agoutis were closely related to E. canis and to genotypes relating to $E$. canis that had previously been detected in free-living animals in Brazil (Figure 2).

Although the role of free-living rodents in the epidemiology of Anaplasmataceae pathogens has been extensively studied in the United States and Europe, there are few reports on the prevalence of Ehrlichia and Anaplasma in rodents in South America. In fact, it was only recently that Ehrlichia spp. and Anaplasma spp. DNA was detected in free-living rodents in Brazil (WOLF et al., 2016; BENEVENUTE et al., 2017).

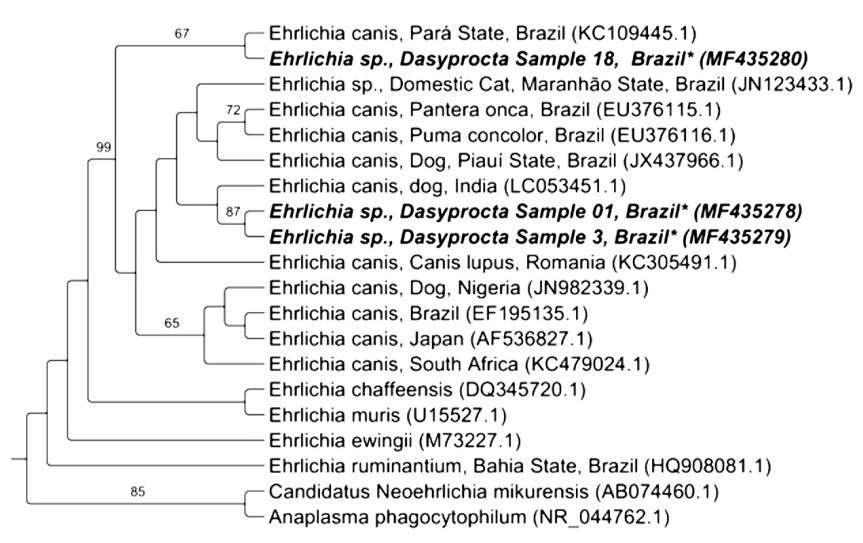

Figure 2. Phylogenetic tree constructed with Ehrlichia spp.-16SrRNA sequences, using Maximum Likelihood method and GTRGAMMA+I evolutionary model. The numbers at the nodes correspond to bootstrap values higher than $50 \%$ accessed with 1,000 replicates, using 'Candidatus Neoehrlichia mikurensis' (AB074460.1) and Anaplasma phagocytophilum (NR_0447621) as outgroups. *The sequences amplified in the present study are highlighted in bold.

Here, all 24 Azara's agoutis were shown to be negative for Anaplasma spp. Previously, one out of 42 rodents sampled in the Pantanal of Mato Grosso was positive for Anaplasma sp., but 
the phylogenetic positioning of this specimen was not accessed. More recently, Benevenute et al. (2017) detected 16S rRNA DNA fragments of Anaplasma sp. in 21 (4.6\%) out of 458 spleen samples from rodents that had been sampled in five distinct biomes in Brazil. The Anaplasma genotypes were detected in rodents from the Caatinga, Cerrado and Atlantic Forest biomes (BENEVENUTE et al., 2017).

In the present study, four Azara's agoutis that were sampled in the Amazon biome were positive for an Ehrlichia genotype closely related to $E$. canis. These findings have been corroborated through the results recently found by Benevenute et al. (2017), who detected a similar genotype in $7(1.5 \%)$ out of 458 rodents belonging to the species Thrichomys pachyurus, Clyomys laticeps, Holochilus fosteri and Calomys cerqueirai, which had been trapped in the Pantanal biome, and Thrichomys laurentius, which had been caught in the Caatinga biome. Interestingly, the genotypes detected in Azara's agoutis were also closely related to an Ehrlichia sp. previously detected in a domestic cat sampled on the island of Sáo Luis (BRAGA et al., 2012). Genotypes closely related to E. canis have also been detected in rodents in Korea (KIM et al., 2006), free-living birds (MACHADO et al., 2012), wild-living carnivores (ANDRÉ et al., 2010, 2012) and domestic cats (ANDRÉ et al., 2015) in Brazil. Unfortunately, attempts to make additional phylogenetic inferences based on genes rather than $16 S$ were unsuccessful, thus corroborating the results found by Benevenute et al. (2017). The real identity at species level of these genotypes that circulate in wild-living rodents in Brazil needs to be further investigated in the future, through isolation, with the aim of achieving better molecular and antigenic characterization.

To the best of the authors' knowledge, the present work showed the first molecular detection of Ehrlichia sp. in Azara's agoutis in Brazil. The pathogenic and zoonotic potential of these genotypes circulating in wild-living rodents in Brazil, their competent vectors and natural cycles need to be further investigated in the future.

\section{Acknowledgements}

We are thankful to Fundação de Amparo à Pesquisa do Estado de São Paulo (FAPESP) and Conselho Nacional de Desenvolvimento Científico e Tecnológico (CNPq) for the financial support to M.R. André (Process numbers \#2015/14896-1 and \#473575/2014-0, respectively).

\section{References}

Altschul SF, Gish W, Miller W, Myers EW, Lipman DJ. Basic local alignment search tool. J Mol Biol 1990; 215(3): 403-410. PMid:2231712. http://dx.doi.org/10.1016/S0022-2836(05)80360-2.

André MR, Adania CH, Machado RZ, Allegretti SM, Felippe PAN, Silva KF, et al. Molecular and serologic detection of Ehrlichia spp. in endangered Brazilian wild captive felids. J Wildl Dis 2010; 46(3): $1017-$ 1023. PMid:20688716. http://dx.doi.org/10.7589/0090-3558-46.3.1017.

André MR, Dumler JS, Scorpio DG, Teixeira RH, Allegretti SM, Machado RZ. Molecular detection of tick-borne bacterial agents in brazilian and exotic captive carnivores. Ticks Tick Borne Dis 2012; 3(4): 247-253. PMid:22749737. http://dx.doi.org/10.1016/j.ttbdis.2012.04.002.
André MR, Herrera HM, Fernandes SJ, De Sousa KC, Gonçalves LR, Domingos IH, et al. Tick-borne agents in domesticated and stray cats from the city of Campo Grande, state of Mato Grosso do Sul, midwestern Brazil. Ticks Tick Borne Dis 2015; 6(6): 779-786. PMid:26187416. http:// dx.doi.org/10.1016/j.ttbdis.2015.07.004.

Benevenute JL, Dumler JS, Ogrzewalska M, Roque ALR, Mello VVC,

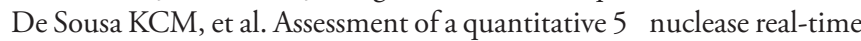
polymerase chain reaction using groEL gene for Ehrlichia and Anaplasma species in rodents in Brazil. Ticks Tick Borne Dis 2017; 8(4): 646-656. PMid:28457822. http://dx.doi.org/10.1016/j.ttbdis.2017.04.011.

Benson DA, Cavanaugh M, Clark K, Karsch-Mizrachi I, Lipman DJ, Ostell J, et al. GenBank. Nucleic Acids Res 2017; 45(D1): D37-D42. PMid:27899564. http://dx.doi.org/10.1093/nar/gkw1070.

Birkenheuer AJ, Levy MG, Breitschwerdt EB. Development and evaluation of a seminested PCR for detection and differentiation of Babesia gibsoni (Asian genotype) and B. canis DNA in canine blood samples. J Clin Microbiol 2003; 41(9): 4172-4177. PMid:12958243. http://dx.doi. org/10.1128/JCM.41.9.4172-4177.2003.

Blaňarová L, Stanko M, Carpi G, Miklisová D, Víchová B, Mošanský L, et al. Distinct Anaplasma phagocytophilum genotypes associated with Ixodes trianguliceps ticks and rodents in Central Europe. Ticks Tick Borne Dis 2014; 5(6): 928-938. PMid:25129860. http://dx.doi.org/10.1016/j. ttbdis.2014.07.012.

Bonvicino CR, Oliveira JA, D’Andrea PS. Gênero Dasyprocta. In: Bonvicino CR, Oliveira JA, D'Andrea PS. Guia dos roedores do Brasil, com chaves para gêneros baseadas em caracteres externos. Rio de Janeiro: Centro Pan-Americano de Febre Aftosa - OPAS/OMS; 2008. p. 82-83.

Braga MSCO, André MR, Freschi CR, Teixeira MCA, Machado RZ Molecular and serological detection of Ehrlichia spp. in cats on São Luís Island, Maranhão, Brazil. Rev Bras Parasitol Vet 2012; 21(1): 37-41. PMid:22534943. http://dx.doi.org/10.1590/S1984-29612012000100008.

Chastagner A, Moinet M, Perez G, Roy E, Mccoy KD, Plantard O, et al. Prevalence of Anaplasma phagocytophilum in small rodents in France. Ticks Tick Borne Dis 2016; 7(5): 988-991. PMid:27270190. http://dx.doi. org/10.1016/j.ttbdis.2016.05.005.

Darriba D, Taboada GL, Doallo R, Posada D. jModelTest 2: more models, new heuristics and parallel computing. Nat Methods 2012; 9(8): 772. PMid:22847109. http://dx.doi.org/10.1038/nmeth.2109.

De Sousa KC, André MR, Herrera HM, Andrade GB, Jusi MM, Santos LL, et al. Molecular and serological detection of tick-borne pathogens in dogs from an area endemic for Leishmania infantum in Mato Grosso do Sul, Brazil. Rev Bras Parasitol Vet 2013; 22(4): 525-531. PMid:24473877. http://dx.doi.org/10.1590/S1984-29612013000400012.

Doudier B, Olano J, Parola P, Brouqui P. Factors contributing to emergence of Ehrlichia and Anaplasma spp. as human pathogens. Vet Parasitol 2010; 167(2-4): 149-154. PMid:19836890. http://dx.doi.org/10.1016/j. vetpar.2009.09.016.

Doyle CK, Labruna MB, Breitschwerdt EB, Tang Y, Corstvet RE, Hegarty BC, et al. Detection of medically important Ehrlichia by quantitative multicolor Taq-Man Real Time Polymerase Chain Reaction of the $d s b$ gene. J Mol Diagn 2005; 7(4): 504-510. PMid:16237220. http://dx.doi. org/10.1016/S1525-1578(10)60581-8.

Dumler JS, Barbet AF, Bekker CPJ, Dasch GA, Palmer GH, Ray SC, et al. Reorganization of genera in the families Rickettsiaceae and Anaplasmataceae in the order Rickettsiales: unification of some species of Ehrlichia with Anaplasma, Cowdria with Ehrlichia and Ehrlichia with Neorickettsia, descriptions of six new species combinations and designation of Ehrlichia 
equi and 'HGE agent' as subjective synonyms of Ehrlichia phagocytophila. Int J Syst Evol Microbiol 2001; 51(Pt 6): 2145-2165. PMid:11760958. http://dx.doi.org/10.1099/00207713-51-6-2145.

Ewing B, Green P. Base-calling of automated sequencer traces using Phred. II. Error probabilities. Genome Res 1998; 8(3): 186-194. PMid:9521922. http://dx.doi.org/10.1101/gr.8.3.186.

Ewing B, Hillier L, Wendl MC, Green P. Base-calling of automated sequencer traces using Phred. I. Accuracy assessment. Genome Res 1998; 8(3): 175-185. PMid:9521921. http://dx.doi.org/10.1101/gr.8.3.175.

Foley JE, Kramer V, Weber D. Experimental Infection of dusky-footed wood rats (Neotoma fuscipes) with Ehrlichia phagocytophila sensu lato. J Wildl Dis 2002; 38(1): 194-198. PMid:11838215. http://dx.doi. org/10.7589/0090-3558-38.1.194.

Inayoshi M, Naitou H, Kawamori F, Masuzawa T, Ohashi N. Characterization of Ehrlichia species from Ixodes ovatus ticks at the foot of Mt. Fuji, Japan. Microbiol Immunol 2004; 48(10): 737-745. PMid:15502406. http:// dx.doi.org/10.1111/j.1348-0421.2004.tb03599.x.

Ismail N, Bloch KC, McBride JW. Human ehrlichiosis and anaplasmosis. Clin Lab Med 2010; 30(1): 261-292. PMid:20513551. http://dx.doi. org/10.1016/j.cll.2009.10.004.

Katoh K, Standley DM. MAFFT multiple sequence alignment software version 7: improvements in performance and usability. Mol Biol Evol 2013; 30(4): 772-780. PMid:23329690. http://dx.doi.org/10.1093/ molbev/mst010.

Kim CM, Yi YH, Yu DH, Lee MJ, Cho MR, Desai AR, et al. Tick-borne rickettsial pathogens in ticks and small mammals in Korea. Appl Environ Microbiol 2006; 72(9): 5766-5776. PMid:16957192. http://dx.doi. org/10.1128/AEM.00431-06.

Kocan AA, Levesque GC, Whitworth LC, Murphy GL, Ewing SA, Barker RW. Naturally occurring Ehrlichia chaffeensis infection in coyotes from Oklahoma. Emerg Infect Dis 2000; 6(5): 477-480. PMid:10998377. http://dx.doi.org/10.3201/eid0605.000505.

Little SE. Ehrlichiosis and anaplasmosis in dogs and cats. Vet Clin North Am Small Anim Pract 2010; 40(6): 1121-1140. PMid:20933140. http:// dx.doi.org/10.1016/j.cvsm.2010.07.004.

Lotric-Furlan S, Petrovec M, Zupanc TA, Nicholson WL, Sumner JW, Childs JE, et al. Human granulocytic ehrlichiosis in Europe: clinical and laboratory findings for four patients from Slovenia. Clin Infect Dis 1998; 27(3): 424-428. PMid:9770134. http://dx.doi.org/10.1086/514683.

Machado RZ, André MR, Werther K, De Sousa E, Gavioli FA, Alves JR Jr. Migratory and carnivorous birds in Brazil: reservoirs for Anaplasma and Ehrlichia species? Vector Borne Zoonotic Dis 2012; 12(8): 705-708. PMid:22607070. http://dx.doi.org/10.1089/vbz.2011.0803.

Massung RF, Slater K, Owens JH, Nicholson WL, Mather TN, Solberg VB, et al. Nested PCR assay for detection of granulocytic ehrlichiae. $J$ Clin Microbiol 1998; 36(4): 1090-1095. PMid:9542943.

Miller MA, Pfeiffer W, Schwartz T. Creating the CIPRES science gateway for inference of large phylogenetic trees [online]. 2010 [cited 2010 Nov 14]. Available from http://ieeexplore.ieee.org/stamp/stamp.jsp?arnumber=5676129

Moraes-Filho J, Krawczak FS, Costa FB, Soares JF, Labruna MB. Comparative evaluation of the vector competence of four South American populations of the Rhipicephalus sanguineus Group for the bacterium Ehrlichia canis, the agent of canine monocytic ehrlichiosis. PLoS One 2015; 10(9): e0139386. PMid:26414283. http://dx.doi.org/10.1371/ journal.pone. 0139386 .
Murphy GL, Ewing SA, Whitworth LC, Fox JC, Kocan AA. A molecular and serologic survey of Ehrlichia canis, E. chaffeensis, and E. ewingii in dogs and ticks from Oklahoma. Vet Parasitol 1998; 79(4): 325-339. PMid:9831955. http://dx.doi.org/10.1016/S0304-4017(98)00179-4.

Nicholson WL, Castro MB, Kramer VL, Sumner JW, Childs JE. Duskyfooted wood rats (Neotoma fuscipes) as Reservoirs of Granulocytic Ehrlichiae (Rickettsiales: Ehrlichieae) in Northern California.J Clin Microbiol 1999; 37(10): 3323-3327. PMid:10488199.

Nieto NC, Foley JE. Reservoir competence of the redwood chipmunk (Tamias ochrogenys) for Anaplasma phagocytophilum. Vector Borne Zoonotic Dis 2009; 9(6): 573-577. PMid:19327022. http://dx.doi.org/10.1089/ vbz.2008.0142.

Nieto NC, Leonhard S, Foley JE, Lane RS. Coinfection of western gray squirrel (Sciurus griseus) and other sciurid rodents with Borrelia burgdorferi sensu stricto and Anaplasma phagocytophilum in California. J Wildl Dis 2010; 46(1): 291-296. PMid:20090047. http://dx.doi. org/10.7589/0090-3558-46.1.291.

Obiegala A, Pfeffer M, Pfister K, Tiedemann T, Thiel C, Balling A, et al. Candidatus Neoehrlichia mikurensis and Anaplasma phagocytophilum: prevalences and investigations on a new transmission path in small mammals and ixodid ticks. Parasit Vectors 2014; 7: 563. PMid:25465390.

Posada D, Buckley TR, Thorne J. Model selection and model averaging in phylogenetics: advantages of Akaike information criterion and Bayesian approaches over likelihood ratio tests. Syst Biol 2004; 53(5): 793-808. PMid:15545256. http://dx.doi.org/10.1080/10635150490522304.

Rar V, Golovljova I. Anaplasma, Ehrlichia, and "Candidatus Neoehrlichia” bacteria: pathogenicity, biodiversity, and molecular genetic characteristics, a review. Infect Genet Evol 2011; 11(8): 1842-1861. PMid:21983560. http://dx.doi.org/10.1016/j.meegid.2011.09.019.

Rejmanek D, Foley P, Barbet A, Foley JE. Antigen variability in Anaplasma phagocytophilum during chronic infection of a reservoir host. Microbiology 2012; 158(Pt 10): 2632-2641. PMid:22859615. http:// dx.doi.org/10.1099/mic.0.059808-0.

Rizzoli A, Silaghi C, Obiegala A, Rudolf I, Hubálek Z, Földvári G, et al. Ixodes ricinus and its transmitted pathogens in urban and peri-urban areas in Europe: new hazards and relevance for public health. Front Public Health 2014; 2: 251. PMid:25520947. http://dx.doi.org/10.3389/ fpubh.2014.00251.

Sanches GS, Évora PM, Mangold AJ, Jittapalapong S, RodriguezMallon A, Guzmán PE, et al. Molecular, biological, and morphometric comparisons between different geographical populations of Rhipicephalus sanguineus sensu lato (Acari: Ixodidae). Vet Parasitol 2016; 215: 78-87. PMid:26790741. http://dx.doi.org/10.1016/j.vetpar.2015.11.007.

Sanger F, Nicklen S, Coulson AR. DNA sequencing with chain-terminating inhibitors. Proc Natl Acad Sci USA 1977; 74(12): 5463-5467. PMid:271968. http://dx.doi.org/10.1073/pnas.74.12.5463.

Santos HA, Thomé SM, Baldani CD, Silva CB, Peixoto MP, Pires MS, et al. Molecular epidemiology of the emerging zoonosis agent Anaplasma phagocytophilum (Foggie, 1949) in dogs and ixodid ticks in Brazil. Parasit Vectors 2013; 6(1): 348. PMid:24330631. http://dx.doi. org/10.1186/1756-3305-6-348.

Stamatakis A, Hoover P, Rougemont J, Renner S. A rapid bootstrap algorithm for the RAxML web servers. Syst Biol 2008; 57(5): 758-771. PMid:18853362. http://dx.doi.org/10.1080/10635150802429642. 
Stover BC, Muller KF. TreeGraph 2: Combining and visualizing evidence from different phylogenetic analyses. BMC Bioinformatics 2010; 11(1): 7. PMid:20051126. http://dx.doi.org/10.1186/1471-2105-11-7.

Sumner JW, Nicholson WL, Massung RF. PCR amplification and comparison of nucleotide sequences from the groESL heat shock operon of Ehrlichia species. J Clin Microbiol 1997; 35(8): 2087-2092. PMid:9230387.

Svitálková Z, Haruštiaková D, Mahríková L, Berthová L, Slovák M, Kocianová E, et al. Anaplasma phagocytophilum prevalence in ticks and rodents in an urban and natural habitat in South-Western Slovakia. Parasit Vectors 2015; 8(1): 276. PMid:25980768. http://dx.doi.org/10.1186/ s13071-015-0880-8.
Walker DH, Ismail N, Olano JP, McBride JW, Yu XJ, Feng HM. Ehrlichia chaffeensis: a prevalent, life-threatening, emerging pathogen. Trans Am Clin Climatol Assoc 2004; 115: 375-382, discussion 382-384. PMid:17060980.

Woldehiwet Z. The natural history of Anaplasma phagocytophilum. Vet Parasitol 2010; 167(2-4): 108-122. PMid:19811878. http://dx.doi. org/10.1016/j.vetpar.2009.09.013.

Wolf RW, Aragona M, Muñoz-Leal S, Pinto LB, Melo ALT, Braga IA, et al. Novel Babesia and Hepatozoon agents infecting non-volant small mammals in the Brazilian Pantanal, with the first record of the tick Ornithodoros guaporensis in Brazil. Ticks Tick Borne Dis 2016; 7(3): 449 453. PMid:26782931. http://dx.doi.org/10.1016/j.ttbdis.2016.01.005. 